\title{
The Review of the International Voices on the Responses of the Worldwide School Closures Policy Searching during Covid-19 Pandemic
}

\author{
Sardjana Orba Manullang 1*, Erwinsyah Satria ${ }^{2}$ \\ ${ }^{1}$ Universitas Krisnadwipayana, Bekasi, Indonesia \\ 2 Universitas Bung Hatta, Indonesia
}

Corresponding Author: Sardjana Orba Manullang, somanullang@unkris.ac.id*

\section{ABSTRACT}

This article was to determine the voice of the international community in responding to the challenges of school closure policies during the 2019 Covid-19 pandemic. Effort to break the chain transmission of Covid-19 was believed to be closely related to the closure of all business activities including schools around the world. In order to understand the impacts and challenges of school closure, a series of critical searches were undertaken on various online sources, for instance news updates publications, practitioners, and school reactions to unplanned global policies to obligate students learning from home. The collecting data was

ARTICLE INFO

Article history: Received

June 29,2020

Revised

August 16, 2020

Accepted

September 1, 2020

How to cite

Journal Homepage

This is an open access article under the CC BY SA license

https:/ / creativecommons.org/licenses/by-sa/4.0/

Published by Covid-19

https://doi.org/10.25217/ji.v5i2.1036 analyzed using a qualitative phenomenological approach and in-depth interpretation to at the collective voice fulfills the reliability and validity of the research problem. The findings indicated that 16 international voices from different perspectives show relatively deep concern about school closures. Voices from these discussions were matched with existing questions and knowledge about difficulties resulting from school closures. The findings of this study can be categorized into three votes; First are voices in support of the national school closure policy. Second, questioning national policies without prior data. Third, there is concern that families face serious challenges in supporting children learning from home with low facilities and the ability to handle student needs. Therefore, these voices would provide essential insights for further decision-making regarding community school participation in supporting of government in fighting the coronavirus epidemic. Hence, a similar study was needed as additional research evidence that helps the government anticipate the spread of this deadly virus, especially in countries and regions experiencing different impacts.

Keywords: School Closure Policy in Covid-19, Learning from Home Policy,

Manullang, S., \& Satria, A. (2020).The Review of International Voices on the Responses of the Worldwide School Closures Policy Searching during Covid-19 Pandemic. Jurnal Iqra' : Kajian Ilmu Pendidikan, 5(2). 1-13.

http://journal.iaimnumetrolampung.ac.id/index.php/ji/

Institut Agama Islam Ma'arif NU (IAIMNU) Metro Lampung

\section{INTRODUCTION}

By the end of 2019, world scientists and medical experts had identified the deadly corona virus disease 2019 (Covid-19) which shook the world's population for the first time since the outbreak appeared (Sohrabi et al., 2020) Guo et al., 2020; Surveillances, 2020). This outbreak confirmed the virus that infected pneumonia, the first outbreak in 
the city of Wuhan, China, which has killed tens of thousands of people as well as impacting whole country economic losses and all human life activities.. Not only does epidemic have many impacts on human health throughout the world but also the economic, physical and mental-being and educational activities that cannot be predicted (World Health Organization, 2020).

As a result of this pandemic, simultaneously in all countries affected by the plague, suddenly countries decided to lock-down and isolated policy in an effort to slowdown the spreading the outbreaks. To response this outbreak, the most impacted countries choose to set their national policy to slowdown of this pandemic by closing public activities and all businesses including the temporary closure of schools both in cities directly affected by the plague and also the ones in remote areas (Weible et al., 2020; Cronert, 2020; Grunert et al., 2020). As a practical solution, most activities are stopped and prefer working from home. While public schools and universities are sending their students learning from home. This policy was an approach to lock the social distancing of the people. It is recognized that the crisis is even harder to do with changes in state rules and policies between economic priority and community safety.

In the response of this Covid-19 outbreak, the obstacles are so big even for the government in advanced countries to response this outbreak as collective global thoughts action. After the government responded of Covid-19 outbreak, teachers and students sent home for learning with as limited resources as possible (Douglas et al., 2020; King et al., 2020). This policy becomes a new world educational trend even though this unplanned choice likes a normal public policy. Similarly, the assessment of learning is also carried out with the help of parents and technological supports even though the belief in the principle of equity and equality of assessment cannot be relied upon by all students. Considering the equal learning as well as assessment for students using just limited learning resources for a short term solution, it is also may result uncertain impact for a long term of educational achievement and challenges.UNESCO (2020) noted that most countries had anticipated the spread of Covid-19 with a policy of temporary closure of schools and universities. One side of this closure is indeed highly undesirable when Indonesia is actively working to catch up in the field of education (Djalante et al., 2020). However, on the other side, as the global is facing a crisis of humanitarian threats from this pandemic outbreak, finally there is no other reason the Indonesia government has to implement this unplanned policy (Jenny, 2020). In response to this outbreak pandemic, several regional heads in Java took the initiative to stop school activities from 16-29 March 2020, while several state universities tried to implement distance learning solutions to help stoping the spread of the corona virus outbreak that had been identified in several major cities in Indonesia with the aim making sure learning continues.

This condition is part of a global issue in responding to the 19 outbreak Covid-19. According to UNESCO, more than 180 countries have implemented a policy of closure on a large scale which impacted the implementation of all final evaluations on students in almost the entire world and this evaluation automatically had to be canceled (WHO, 2020). UNESCO (April 14) has investigated more than 188 countries globally had canceled altogether schools, affecting more than 1.5 billion school children and no less than 90 percent of the total students. The World Experience has never had a devastating impact this time on efforts to increase human resources since the widespread spread of the Corona virus is very detrimental to the economic, social, and political aspects that continue to last. 
Realizing on this school closures is undeniable that the majority of the world's citizens feel a great fear that educational status in each country and the drop of each school learning achievement worldwide particularly in many unstable ones who have been very alert in responding to this Covid-19. McKibbin and Fernando (2020) concern on the impact and risk of school disclosure on academic achievement. It is very potential because of this impaired continuity of learning and teaching that replace to learning from home. It also impact on social economy and turn to global crisis. In response to this pandemic, the government through the school together with the community, especially parents, must be acknowledged, already showing that they are increasingly focused on a variety of learning solution strategies, including continuing the learning process at home. For example, with the use of technology, teachers coordinate the learning process of students using What App application, where all parents are connected together (Xie and Yang, 2020).

Hence, to understand the difficulties and challenges that most schools and education stakeholders have in the second period of school closure, the authors reviewed and evaluated their potential opinions either optimistic and expectation with deep concerns about school closure as a collaborative effort with the world community to slow the spread of the corona virus as a plague that has had an increasingly widespread impact (Golberstein et al., 2020; Lynn et al., 2020; Tanhan et al., 2020). The typical challenges faced by most parents and students as they have to learn from home will be the main discussion of this study. This challenge of learning from home is believed to have a lot adaptability and struggle that students and teachers have to do. Such struggle of technical and technological issue including human (parents) resources who facilitate the learning support. Wang et al., (2020) noted that their experiences in china during outbreaks, the students and teachers personal learning motivations are also important and becoming an influenced factor of learning from home success. They investigated similar issues after in whole states after covid-19 outbreak in their home country. Viner et al., (2020) reported that more than 100 countries have been implemented school closures and resulting serious concern over students learning difficulties. This situation has becoming global impact on education especially the study done from home. Reich et al., (2020) reviled that school closures after Covid=19 outbreaks resulting difficulties including learning control and supervision as normal learning in school.

This pandemics response related to the effect on the course of education throughout the world is very important to carry out especially when the world facing an increase in educational disruptions by this pandemic disease. Therefore, the results of study would be able to contribute insight and mindset of education managers either at the central government level as policy makers, teachers, parents and the community. In line with Gates (2020) in respond to Covid-19 as 21 century pandemic, he advised that the demands for the involvement of educational technology would be very helpful in responding to every present and future challenge. Likewise, the role of international and national mass media, schools or teachers and parents must adapt to technological developments in serving the demands of education in the 21 st century. Hence, this study felt to be very necessary to be conducted.

\section{METHODS}

To understand the typical challenges resulting from the school closure policy of the Covid-19 pandemic as they responded to school sending students home to study, a number of online discussions searching and analysis from around the world who put 
deep concern about the those policy impacts on education practices are analyzed and raised critically from March 15 to June 20, 2020. The voices were chosen because of ideas were different from one another which were in line with this research question. The steps taken to process this data were searching, copying the content of discussion, comments, opinions and updates posted online. Then all the results of the discussion become a simple set of informative data especially for educational concern parties (Hewson \& Stewart, 2016). All data related responses were searched using keywords such as "school Closures", "corona virus or covid-19", "stay and learn from home", and "covid 19 impacts" (Ayyoubzadeh et al., 2020). All data were reviewed ensuring met the research questions. Each relevant data were immediately labeled as the main information that would be reviewed in the findings and discussion. In this case, the effort to review all relevant information was very important in identifying responses posted that meet the response criteria that were relevant to the research questions investigated, responsible and directly related to the international response of the corona virus 2019 pandemic and its impact on education resulting from the school closure policy globally.

\section{RESULT AND DISCUSSION}

This section details the main findings of answers to research questions about the educational challenges of the effects of each country's government policy on closing schools after Covid-19 engulfed the world. The policy of laying off students is done to save lives and continue learning at home during the outbreak. As a result of this sudden policy has left serious difficulties experienced by thousands of millions of schools, students and parents throughout the world. This decision also shows the psychological impact on students sent home to study while saving lives is an educational challenge that requires collective support from the community and global leaders Wang et al., (2020) suggested that helping children during confinement while continuing to study at home during the outbreak was very important. For this reason, the researchers are interested in understanding these numerous international voices especially the information on the Covid responses impacting students learning that has been globally reported.

Rathjen, (2020) said that the University of Adelaide are inviting all alumni taking part in the COVID-19 students support the program. Through the university chancellor, the university community express their concern to help their most impacted students. This is the point the chancellor said:

Many of our students; Domestic, international, postgraduate courses and Higher Degrees by Research, face a combination of stresses, being isolated from their families, and their support networks. This has been compounded by significant job losses.

One of the national online news Duffy and Scott (2020) reported that the president of the Republic of Indonesia, Joko Widodo spoke to medias addressing a new policy on the Covid 19 responds over learning from home face more difficulties. The following points highlighted are:

For parents and guardians of students, this policy in the Covid 19 era, the learning movement only at home is also very challenging for many parties, especially parents who do not have supported conditions, including the government itself, which sometimes only gives instructions but is not followed by adequate facilities and teacher resources that can actively manage learning remotely. 
Here most challenges are the readiness of government and schools to send the students home with lack of learning supports. This is so true as this new learning from home policy is a sadden one to response Covid-19 outbreak.

The Guardian edition 7 April 2020 speaking referring to the UN body for education and culture, UNESCO which stated that no less than $90 \%$ of students in the world had been affected by the closure of schools as an effort to respond to this corona virus disease 2019. The following is a paraphrasing the headline news.

It is very likely that the closure of schools has very little impact on the transmission of the corona virus. The countries that are not seriously impacted must consider wisely for both losses and benefits to the economic and education conditions seriously, especially the education of children who are less able to full supports of their education from home.

The Guardian voiced the school closures were not much impact on corona virus spreading among students. They added the countries should have considered from both sides advantages and disadvantages from school closing in term of economic and students challenge as they are returning home to study with little supports.

Similar concern is also come from The New York Times, 6 April 2020 on Asia Pacific coverage. This edition does not put good truth to the government policy on closing schools and returning students home to learning. The newspaper said that by cited many academic paper evidences. They said closing schools are not strategic policy to control the Covid-19 impacts. Here is the points:

We know from previous studies that school closures are likely to have the greatest effect if the virus has low transmissible and attack rates are higher in children. This is the opposite of Covid-19 (Vine, 2020).

The New York Times spoke that the closures of schools is not a sole solution to stop virus spreading among students. This speaking was supported by evidences from various researches of university (Weale, 2020).

While the New York Times and the Guardian see this closing school policy is worse to combat the virus, the Education-Next Digest responded differently by questioning the attention of government leaders during the Corona virus outbreak. What assistance can all states provide to help schools after they send students home and continue to study: The phrase Education Next regarding Covid-19 and the reactions of various parties that have had an impact on the education were conveyed in its coverage. Rick from Education Next asked Deputy Superintendent in Idaho State to response. Here is the some answers:

Since the outbreak, the state of Idaho responded with directly closing schools in all districts. The students switch to online at home. The state remains enthusiastic about providing facilities, delivering food and health care services for children. The State ensures students and teachers learn in a healthy environment away from infectious diseases. The states are obliged to serve the most basic needs in flexible ways, new innovations, requesting the services of city bus drivers to help deliver packages of staple foods, homework, and Wi-Fi Hotspot facilities.

The school closures policy was so positively responded including Idaho and all districts. The responses with all facilities ranging from learning facilities, Internet connection, medical assistant and food delivery for students at home learning.

The next respond is from the New York Times opinion editorial board, edition 27 March 2020. This edition views pandemic corona virus has resulted the schools of all states in USA force on students learning from home with the lack of online connectivity. The opinion also expressed the concern on the condition of tens of 
millions of school children who could not get internet access even before the outbreak corona case for homework. These what the paper concerned (Editorial, 2020):

The paper considered the school system is forced to learn online with lacks Internet services. Similarly, there are districts that experience very low learning service infrastructure so that they no longer rely on distance learning. So there are also those who are hesitant by forcing themselves to carry out teaching online because their impact may be questioned by the court for imposing learning that cannot be done by families who do not have broadband facilities.

This opinion from the New York Times editorial board expressed their concern over the students learning at home with the lack of learning facilities experienced by tens of thousands of children in USA even before the Covid 19 outbreak. The Sydney Morning Herald questioned why the government did not implement the full school closure policy during the corona virus pandemic though the application of social distancing behavior continues. This concerns the fate of the safety of 4 million Australian students. Then the newspaper explained on what basis the decision to not close all schools during the occupiers was reviewed (Bungard, 2020).

The reason for this newspaper is that they see that when children are laid off, more and more parents have to look after their children and thirty percent of medical crews must stay home to look after their children. Besides, children are more susceptible to viruses when they are in the social environment than in the school care area.

A scientific article from Research-Based Policy Analyses edition 1 April 2020 put concern on school closing by exploring how education, skills, and learning has impacted by Covid-19. According this article, global isolation of educational institutions will disrupt learning including evaluation of students learning outcomes, the national exams of each country. This column also discusses all methods that can be taken so that the country can minimize the greater impact. Here this article stressed on the serious impacts as school closures policy:

Going to school is the best way for children to gain knowledge and future skills.

Besides that children also will continue to have fun and the opportunity to socialize.

When children have to be sent to parents, then this is a thing never thought of. Not only it has taken time for working parents to remain at home, but also this is a moment where all the difficulties of adaptation will continue. This is really an interruption that must be sought for a solution.

Again a scientific paper proving that this school closing policy is not always a best solution of Covid-19 respond. This paper really understands this policy needs other solution as the policy of sending students home during outbreak remains more interruptions.

National Indonesian newspaper Compas.com spoke about the difficulty faced by most parents as they have to be at home working and supporting kids learning with their limited ability to functioning teacher roles. The followings were the conversations of two of parents from Jakarta. Here is the what they said:

To be honest, many parents do not have the ability like school teachers. So, children become bored quickly," said Child Protection Specialist UNICEF Indonesia, Astrid Gonzaga Dionisio in a press conference at BNPB, Thursday (2/4/2020). "Our children are dynamic, energetic, according to their development, they want to be close to their friends. Moreover, teenagers are more comfortable with peers than their parents when learning. 
The Kompas.com response school closing by speaking to one of Indonesian UNICEF child protection specialist. The challenge faced by most parents was the ability of parents to functioning the teachers roles at home learning circumstances.

District Alsea School as spoken by Thielman (2020), their typical respond after the governor's executive order on school closure until 28 April and re-extended to all students to stay home to save life from Covid-19 spreading. Here what the school said:

We have to keep continue to delivery education supports, school meals, emergency supplemental, paying employee bills. More importantly schools and government greatly appreciate for value information and communication in response the Covid crisis with so flexible where everything could in outside government control"

Status update on social media by one of parents from Indonesia. He understands that the children have to stay and study from home with lack of school help. As the teachers keep sending the work regularly every week., the children have to do the work even no experience having homework only instead, they require their parents to support and help do the works. The father who was a former of teacher and said:

When I was a teacher, I only taught one or two subjects in schools. But now since my children have to study from home, there are already many subjects that I have to do supporting them, with many different subjects even the subject of Arabic Course. Luckily, I still remember some at my own school

Since outbreak and governments worldwide make a sudden policy sending students home and waiting for school reopens, more status update of parents expressing their double functioning in between working from home and supporting their kids learning.

A Columnist reported his respond on the school closures as a global policy. He put his concern on isolated learning after corona virus disease outbreaks. The columnist said:

This is the perfect time to prepare a house to replace school. He has a friend named Heather who has several children who are still in elementary school. Like in other parts of the world, after the plague shook the world, all schools suddenly send their students home. Likewise, the state of San Francisco is under the control of the government with the best protection in the country. But thanks to good support ahead of the second week of homeschooling, all the families there can make their children learn well

Singapore's Ministry of Education, Mr Ong Ye Kung spoke to reporters about his response to the reopening of the school during the Covid period. He expressed the concern of most parents now about the government's next plan to reopen schools. For this reason, he adheres to the results of research, strict precautions are maintained, and his desire to stop the reduction of educational disruptions is a top priority and full consideration in reopening schools. The minister said:

Part of the reason for the tougher border measures is to ensure we keep Singapore as safe as possible, so that daily activities, like going to work, eating out and attending school, can go on.

KCRA news podcast on March 23, 2020, expressed his concern about how to deal with children who had suddenly been laid off and continued to study under the control and guidance of parents during an outbreak. This is really a difficult time, especially now having two small children and coupled with the return of their brother who is studying at university. Parents say this is a big shift in learning for students with parents.

This is really a difficult time having to escort small children full time at home during the plague plus university students returning unexpectedly. What a difficult time of 
transition. The phrase Kellie Randle, a student parenting specialist shares tips with parents whose children are returned home after outbreak. This is the family's as a solution that must manage family members at home for days in the difficult period.

Online Australian famous radio broadcast service, ABC released school closures to response covid outbreak. At the beginning of out-broke, day by day it is very worrying even quite a lot of panic with the name of the deadly virus that strikes the countries worldwide. The parents are no exception very restless and anxious whether children should just stay at home while there is no official announcement.

Form of concern for many parents in Australia is by urging the government to escort children from the dangers of the deadly virus. So the Government through its own study also agrees with the calls of parents so that children can be saved and continue to study from home temporarily. This is as an effort of social isolation. The government's decision may surprise the public at first. More and more after the other hemisphere of the earth they had first acted before the effects of the plague got worse.

The THE Journal edition, Challenges of Learning from Home. Here this journal said:

The views of the experts from the Higher Education journal, the transformation section of higher education through technology empowerment, conveyed the deep concern that when they were actively promoting online learning when the outbreak could not be controlled, they asked all parties not to forget the total needs of children.

This paper really put concern home learning is a great solution to anticipate covid-19 solution. However, parents should put more control as well as understand the needs of most students learning.

To participate in the Covid-19 global responses, English Mastery provides a free source of home learning after the government implements school closures. They do this to help students benefit the same routines, models and treatments that students normally get from their own regular school lessons (Shahroodi, 2020).

Students may search all learning materials they need just by clicking on the relevant materials to their school years. All lessons adjusted as school curriculum including guide for use and parents controlled. All are for free and unlimited for students worldwide.

The objective of this study is to understand the international voices over the educational challenges resulting from global school closures policy to response the spreading of the novel corona-virus. Based on 16 websites searched, the voices can be divided into 3 categories; expected, unexpected, existing voices expressing their concern over school closures policy in each country being searched.

In many countries as newspaper searched expressed their concern on the difficulties faced by parents as they have to support their children learning from home. The majority of newspaper said that they are worries of the parents readiness to support the children learning. For example what Tribunnews.com edition 7 April 2020 wrote that the big difficulties are the readiness of the parents to handle children learning. Starting from ability to use technology and the pedagogical ability to approach the typical teenager learning. This national challenge on education in every country impacted by Covid-19 has a strong connection with the condition released by the Normal University in Beijing and UNESCO release early this year. Huang, R.H et al., (2020) findings confirmed that the world now are coming together solving the learning problem after the Covid 19 outbreak worldwide. They found evidences in each country are differently in solutions. Some governments have successfully responded with the hi-technology supporting their students learning from home (Daniel, 2020). For most schools in not well development countries responded with 
low-technology while some other countries responded their students learning from home with no-technology at all.

Searching the Guardian newspaper and UNESCO release, both said that it is very likely that the closure of schools simultaneously in many countries has very little effect on the transmission of the 2019 corona virus. When returning to the issue of the development of Covid-19, their statement was very contrary to what was predicted by many medical experts, especially Chinese medical, the country of origin of this virus was confirmed by the world health agency ( $\mathrm{Wu}$ et al., 2020). This indicates that all countries adopted a school closure policy not based on expert study data as a joint guide in responding to Covid-19 (Viner et al., 2020). If in the future schools are forced to close, the field study is very important for every country to have a fundamental reason for closing schools and continuing to study at home. In other words references to valid data must be a priority, not because of panic reason.

When noticing the voice from the New York Times editorial opinion response, March 27, 2020 which expressed the concern of tens of millions of students who could not access the internet even long before this outbreak. This fact is so strange when connected with most media said about real condition of education in most modern nation like USA. Maybe as it is what happen to other nations in respond the student study from home policy, it became a challenge to the student learning from home gap. The opinion added that Covid-19 has added to the burden on the family in each local government that continues to struggle to provide fair teaching for each family. Since the school closing policy in responding to the spread of this deadly virus, this opinion assesses all parties as forcing students to be discharged and to learn with their mind. But this opinion also appreciated that there are districts that experienced very low learning service infrastructure so that they no longer depend on distance learning on the grounds of inadequate supporters such as internet access that can be relied upon by remote villages.

Opinion from with the New York Times editorial, 27 March 2020 expressed the concern of tens of millions of students who could not access the internet even long before this outbreak. Coupled with this policy, parents are increasingly challenged by the gap between one family and another. On this basis the local government continues to struggle to provide fair teaching for every family. This opinion sees the school closing policy responding to the spread of this deadly virus to many parties such as forcing students to be sent home to study with the limited support resulting education practice turning worse. Ending its opinion the paper put the appreciation to a number of districts where education service infrastructure was still low and do not force the families to go online learning. Carver (2020) noted that as the students are returning home to continue learning, more challenges are confronting them that its so necessary to support them during the crisis time.

The finding of the Research-Based Policy Analysis points out that the closure of schools as a joint response to the Covid-19 outbreak has isolated educational institutions around the world by interrupting student learning so seriously including final evaluation and national exams in each country. To address this disruption, this article suggested that all approaches can be taken so that the each country can minimize the impact. Similar study done by Setiawan (2020) working with primary students during the learning from home period in response Covid-19. He designed and supported students learning with more worksheet topic on pandemic issues and finds out that students learning disruption and impacts can be reduced. 
The difficulty faced most parents in supporting students learn from home was also searched from a status update on social media by one of parents from Indonesia. Llewellyn (2020) study suggested that parents shall support students learn from during covid 19 outbreak not only for learning reason but also for psychological support. Cao et al., (2020) the results of their study noted that student learning needs strong social support not only for learning but also for students' health especially for students from good families who are certainly very economically helpful for students during continuous education.

In response students learning from home, the readiness of parents is another plus in supporting students working on school lessons. In this case, the students require their parents full support. In fact, not many parents have ability and times much to sit and provide guide. UNICEF (2020) advised the role of parents are so helpful as family support with online learning options to ensure continued learning under the full support from each schools for maximum student learning from home (OwusuFordjour et al., 2020). They noted that the impact of pandemic on learning in whole country was large that has drop learning outcomes.

\section{CONCLUSIONS}

More than 100 countries have adopted policies to close schools taking part in maintaining social distance during the Corona 2019 outbreak. However, because this school closure policy is very sudden, it is necessary to review various information while understanding the voices of the world community from various elements because their voices will very helpful for next anticipatory steps. In other words, international voices can be a material for review to understand the impact of the school closures policy during the Covid-19 pandemics. This is reminiscent of quite a number of countries that have implemented policies to close schools without being based on indepth studies of the extent to which these policies have proven to be able to reduce the spread of the corona virus in countries and regions that are not in the Covid-19 red zone category. The results of this study indicate that there are various views from the international community who are concerned about closing schools to respond to the spread of Covid-19. In general their voices can be divided into three categories. First, voices that express concern to support national policies on school closure and hope the government fully supports students learning from home. Second, the voices regarding government policies for school closure without prior research data whether students' social distance has proven an effective approach to combat the spread of the corona virus. Third, voices that question the great challenges faced by most parents in supporting students to learn from home with limited learning facilities. The study also puts concern that educational success is the most important factor in achieving health status and the success of a country's future generations. So this research can conclude the impact of school closure in uncertain times, so the concern about the quality of education of the young generation of a nation needs to be studied in more depth what are the advantages and disadvantages of responding to each crisis.

\section{ACKNOWLEDGEMENTS}

This research has been carried out as a part of a number of university-funded studies entitled, "Review of the International Voices on Responses of the Worldwide School Closures Policy Searching During Covid-19 Pandemic", a series of studies sponsored by DRPM funding of the Ministry of Research, Technology and Higher Education, Republic of Indonesia. Thanks to the government of the Republic of 
Indonesia for the research provided with a grant scheme: research of novice lecturers in 2020. Thanks to all for the support that has given to both authors so that it can be completed on time. Thank you also to all the news media for their contribution to the gathering effort data during the Covid-19 crisis.

\section{AUTHOR CONTRIBUTION STATEMENTS}

Sardjana Orba Manullang (SM) as the main author of this project. Meanwhile, Erwinsyah Satria (ES) as the second author who has professionally provided academic support. ES was a co-author in carrying out this research from start to finish. SM as the main researcher was currently working at the University of Krisnadwipayana, Bekasi and as a senior teaching staff. Meanwhile, ES is currently being listed as a lecturer and research officer at Bung Hatta University. ES has been a collaborative partner for this project with her expertise in data analysis and draft writing. His role was very supportive from the start to the completion of the project "Review of the International Voices \& Responses of the Worldwide School Closures Policy Searching During Covid19 Pandemic".

\section{REFERENCES}

Ayyoubzadeh, Seyed Mohammad, Ayyoubzadeh, Seyed Mehdi, Zahedi, H., Ahmadi, M., Kalhori, S.R.N., 2020. Predicting COVID-19 Incidence Through Analysis of Google Trends Data in Iran: Data Mining and Deep Learning Pilot Study. JMIR Public Health Surveill. 6, e18828. https:/ / doi.org/10.2196/18828

Bungard, S.K., Lucy Cormack, Matt, 2020. Coronavirus updates LIVE: Morrison government locks in COVID-19 independent review with EU support as global cases top 4.5 million, Australian death toll at 98 [WWW Document]. Syd. Morning Her. Google Scholar

Cao, B., et all. 2020. A Trial of Lopinavir-Ritonavir in Adults Hospitalized with Severe Covid-19. N. Engl. J. Med. 0, 1-13. https:/ / doi.org/10.1056/NEJMoa2001282

Carver, L.B., 2020. Supporting Learners in a Time of Crisis. Adv. Soc. Sci. Res. J. 7, 129136. https:// doi.org/10.14738/assrj.74.8109

Cronert, A., 2020. Democracy, state capacity, and covid-19 related school closures.

Daniel, S.J., 2020. Education and the COVID-19 pandemic. PROSPECTS. https:/ / doi.org/10.1007/s11125-020-09464-3

Djalante, R., Shaw, R., DeWit, A., 2020. Building resilience against biological hazards and pandemics: COVID-19 and its implications for the Sendai Framework. Prog. Disaster Sci. 6, 129-136. https:/ / doi.org/10.1016/j.pdisas.2020.100080

Douglas, M., Katikireddi, S.V., Taulbut, M., McKee, M., McCartney, G., 2020. Mitigating the wider health effects of covid-19 pandemic response. BMJ 369, m1557. https:// doi.org/10.1136/bmj.m1557

Duffy, C., Scott, S., 2020. Should I keep my children home from school due to coronavirus? - ABC News [WWW Document]. URL https://www.abc.net.au/news/2020-03-16/ should-i-keep-my-children-homefrom-school-due-to-coronavirus/12058200 (accessed 5.17.20).

Editorial, 2020. Breaking News, World News \& Multimedia [WWW Document]. URL https:// www.nytimes.com (accessed 5.17.20).

Gates, B., 2020. Responding to Covid-19 - A Once-in-a-Century Pandemic? N. Engl. J. Med. 382, 1677-1679. https:/ / doi.org/10.1056/NEJMp2003762 
Golberstein, E., Wen, H., Miller, B.F., 2020. Coronavirus Disease 2019 (COVID-19) and Mental Health for Children and Adolescents. JAMA Pediatr. https://doi.org/10.1001/jamapediatrics.2020.1456

Grunert, P.C., Reuken, P.A., Stallhofer, J., Teich, N., Stallmach, A., 2020. Inflammatory Bowel Disease in the COVID-19 Pandemic-the Patients 'Perspective. J. Crohns Colitis. Google Scholar

Guo, Y.-R., Cao, Q.-D., Hong, Z.-S., Tan, Y.-Y., Chen, S.-D., Jin, H.-J., Tan, K.-S., Wang, D.-Y., Yan, Y., 2020. The origin, transmission and clinical therapies on coronavirus disease 2019 (COVID-19) outbreak - an update on the status. Mil. Med. Res. 7, 11. https:/ / doi.org/10.1186/s40779-020-00240-0

Hewson, C., Stewart, D.W., 2016. Internet Research Methods, in: Wiley StatsRef: Statistics Reference Online. American Cancer Society, pp. 1-6. https:/ / doi.org/10.1002/9781118445112.stat06720.pub2

Huang, R.H, Liu, D.J, Tlili, A, Yang, J.F., Wang, H.H, 2020. Handbook on Facilitating Flexible Learning During Educational Disruption. Smart Learning Institute of Beijing Normal Universit, Beijing. Google Scholar

Jenny, F., 2020. Economic Resilience, Globalization and Market Governance: Facing the COVID-19 Test (SSRN Scholarly Paper No. ID 3563076). Social Science Research Network, Rochester, NY. https:/ / doi.org/10.2139/ssrn.3563076

King, T., Hewitt, B., Crammond, B., Sutherland, G., Maheen, H., Kavanagh, A., 2020. Reordering gender systems: can COVID-19 lead to improved gender equality and health? The Lancet 396, 80-81. Google Scholar

Llewellyn, S., 2020. Covid-19: how to be careful with trust and expertise on social media. BMJ 368. https:// doi.org/10.1136/bmj.m1160

Lynn, R.M., Avis, J.L., Lenton, S., Amin-Chowdhury, Z., Ladhani, S.N., 2020. Delayed access to care and late presentations in children during the COVID-19 pandemic: a snapshot survey of 4075 paediatricians in the UK and Ireland. Arch. Dis. Child. Google Scholar

McKibbin, W.J., Fernando, R., 2020. The global macroeconomic impacts of COVID-19: Seven scenarios. Brookings. URL https://www.brookings.edu/research/theglobal-macroeconomic-impacts-of-covid-19-seven-scenarios/ (accessed 5.16.20).

Owusu-Fordjour, C., Koomson, C.K., Hanson, D., 2020. The impact of covid-19 on learning - the perspective of the ghanaian student. Eur. J. Educ. Stud. 0. https:/ / doi.org/10.46827/ejes.v0i0.3000

Reich, J., Buttimer, C.J., Fang, A., Hillaire, G., Hirsch, K., Larke, L., Littenberg-Tobias, J., Moussapour, R.M., Napier, A., Thompson, M., Slama, R., 2020. Remote Learning Guidance From State Education Agencies During the COVID-19 Pandemic: A First Look (preprint). EdArXiv. https:// doi.org/10.35542/osf.io/437e2

Selfe, C.L., Hugh BURNS, 1999. Technology and Literacy in the 21st Century: The Importance of Paying Attention, 1st edition. ed. Southern Illinois University Press, Carbondale, IL. Google Scholar

Setiawan, A.R., 2020. Scientific Literacy Worksheets for Distance Learning in the Topic of Coronavirus 2019 (COVID-19). Google Scholar

Shahroodi, M., 2020. Free home learning resources during Coronavirus school closures. Engl. Mastery. URL https://www.englishmastery.org/our-response-tocoronavirus-covid-19/ (accessed 5.17.20).

Sohrabi, C., Alsafi, Z., O'Neill, N., Khan, M., Kerwan, A., Al-Jabir, A., Iosifidis, C., Agha, R., 2020. World Health Organization declares global emergency: A 
review of the 2019 novel coronavirus (COVID-19). Int. J. Surg. Lond. Engl. 76, 71-76. https:/ / doi.org/10.1016/j.ijsu.2020.02.034

Surveillances, V., 2020. The epidemiological characteristics of an outbreak of 2019 novel coronavirus diseases (COVID-19) - China, 2020. China CDC Wkly. 2, 113-122.

Tanhan, A., Yavuz, K.F., Young, J.S., Nalbant, A., Arslan, G., Yıldırım, M., Ulusoy, S., Genç, E., Uğur, E., Çiçek, İ., 2020. A Proposed Framework Based on Literature Review of Online Contextual Mental Health Services to Enhance Wellbeing and Address Psychopathology During COVID-19. Electron J Gen Med. 2020; 17 (6): em254. Google Scholar

Thielman, M., 2020. Administrative Staff [WWW Document]. Alsea Sch. Dist. URL http://alsea.k12.or.us/district-office/administrative-staff/ (accessed 5.17.20).

Viner, R.M., Russell, S.J., Croker, H., Packer, J., Ward, J., Stansfield, C., Mytton, O., Bonell, C., Booy, R., 2020. School closure and management practices during coronavirus outbreaks including COVID-19: a rapid systematic review. Lancet Child Adolesc. Health 4, 397-404. https://doi.org/10.1016/S23524642(20)30095-X

Wang, G., Zhang, Y., Zhao, J., Zhang, J., Jiang, F., 2020. Mitigate the effects of home confinement on children during the COVID-19 outbreak. The Lancet 395, 945947. https:/ / doi.org/10.1016/S0140-6736(20)30547-X

Weale, S., 2020. School closures likely to have little impact on spread of coronavirus, review finds. The Guardian. Google Scholar

Weible, C.M., Nohrstedt, D., Cairney, P., Carter, D.P., Crow, D.A., Durnová, A.P., Heikkila, T., Ingold, K., McConnell, A., Stone, D., 2020. COVID-19 and the policy sciences: initial reactions and perspectives. Policy Sci. 53, 225-241. https://doi.org/10.1007/s11077-020-09381-4

WHO, 2020. Coronavirus Disease (COVID-19) - events as they happen [WWW Document]. URL https://www.who.int/emergencies/diseases/novelcoronavirus-2019/events-as-they-happen (accessed 5.16.20).

World Health Organization, 2020. Mental health and psychosocial considerations during the COVID-19 outbreak, 18 March 2020. Google Scholar

Wu, C. et al., 2020. Risk Factors Associated With Acute Respiratory Distress Syndrome and Death in Patients With Coronavirus Disease 2019 Pneumonia in Wuhan, China. JAMA Intern. Med. https:// doi.org/10.1001/jamainternmed.2020.0994

Xie, Z., Yang, J., 2020. Autonomous Learning of Elementary Students at Home During the COVID-19 Epidemic: A Case Study of the Second Elementary School in Daxie, Ningbo, Zhejiang Province, China. Best Evid. Chin. Educ. 4, 535-541. https://doi.org/10.15354/bece.20.rp009

Copyright Holder :

(c) Manullang, .S., \& Satria, E. (2020).

First Publication Right :

(C) Jurnal Iqra' : Kajian Ilmu Pendidikan

This article is under:

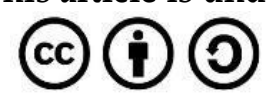

